\title{
Biological parameters and population structure of Psammobatis extenta in Ubatuba region, north coast of the State of São Paulo, Brazil
}

\author{
Itamar A. Martins* ${ }^{\ddagger}$, Camila L. Martins ${ }^{\dagger}$ and Maria Helena de A. Leme* \\ *Universidade de Taubaté, UNITAU, Departamento de Biologia, Laboratório de Zoologia, 12030-010, Taubaté, SP, Brazil. \\ ${ }^{\dagger}$ Universidade Estadual Paulista, UNESP, Departamento de Zoologia, 18618-000, Botucatu, SP, Brazil. \\ ${ }^{\ddagger}$ Corresponding author, e-mail: istama@uol.com.br
}

\begin{abstract}
Specimens of the zipper sand skate Psammobatis extenta were collected in the region of Ubatuba off the northern coast of the State of São Paulo, Brazil, monthly for one year (January-December 2000), at 25- to 40-m isobaths. A total of 123 individuals were caught. The total length (TL) of females averaged $224.6 \mathrm{~mm}$, and of males $217 \mathrm{~mm}$. The overall sex ratio was 1:1. Analysis of the length-weight relationship indicated the existence of positive allometry in females, and isometry in males. The length at onset of sexual maturity was determined for both sexes; females reached sexual maturity at smaller sizes than males $\left(\mathrm{TL}_{50}=230.7\right.$ and $\mathrm{TL}_{50}=237.7 \mathrm{~mm}$ respectively). Females showed functional parity of both ovaries and uteri. Females that were pregnant or were carrying vitellogenic oocytes were observed during nine of the 12 months of the survey, indicating a continuous reproductive cycle. Psammobatis extenta was most abundant from January to April, and again from June to October. Most individuals were collected at the 40-m isobath. Both adults and neonates were collected in the study area. However, adolescent skates were scarce, which either indicates differential occupation of the area, or suggests that the shallow waters of the continental shelf are used as breeding grounds.
\end{abstract}

\section{INTRODUCTION}

The coast of the State of São Paulo is part of the Argentinean Marine Zoogeographical Province, which includes the region from Cabo Frio in the State of Rio de Janeiro, Brazil, south to the Península Valdés in Argentina (Figueiredo, 1981). This area is a hydrological and faunistic transition zone, which harbours as many typical tropical as temperate species, in addition to its endemic residents (Figueiredo, 1981; Mahiques, 1995).

The northern coast of São Paulo is influenced by three types of water masses with distinct characteristics: the South Atlantic Coastal Water (SACW), Tropical Water (TW), and Coastal Water (CW). These water masses modify the temperature, salinity, and nutrient contents during the seasons, altering the distribution of the inhabitants of the region (see Matsuura, 1986; Pires, 1992).

For the coast of São Paulo, 12 orders, 28 families, 44 genera, and 86 species of cartilaginous fish are presently recognized. The skates and rays are represented by 9 families, 16 genera, and 31 species (Gadig, 1998). The family Rajidae is the most prominent, with nine species, seven of them endemic to the Argentinean Marine Zoogeographical Province (Figueiredo, 1981). The genus Psammobatis Günther, 1870 is represented off the Brazilian coast by the zipper sand skate P. extenta (Garman, 1913), the spade sand skate $P$. rutrum Jordan, 1891, the freckled sand skate $P$. lentiginosa McEachran, 1983, and the blotched sand skate P. bergi Marini, 1932. Psammobatis extenta occurs from Cabo Frio (Rio de Janeiro) in Brazil as far south as Patagonia in Argentina (Norman, 1937). It is found off the coast, at depths of approximately $20 \mathrm{~m}$ down to $115 \mathrm{~m}$
(Figueiredo, 1981; Rossi-Wongtschowski \& Paes, 1993). Psammobatis extenta (a senior synonym of Psammobatis glansdissimilis McEachran, 1983 (Carvalho \& Figueiredo, 1994) is endemic to the Argentinean Marine Zoogeographical Province (Figueiredo, 1981).

Most of the previous studies of the Brazilian coast fish fauna have focused on teleosts and have largely ignored the elasmobranchs, especially the skates and rays. The great majority of the existing records are from faunal surveys or unpublished theses, which makes it difficult to access information about the local species of skates.

The purpose of the present investigation was to analyse certain aspects of the biology of $P$. extenta in the Ubatuba region, such as the population size structure, the size at onset of maturity, and its spatial and temporal distribution. This information will form part of the basis of management plans for the living resources of this region.

\section{MATERIALS AND METHODS}

The work was carried out in the region of Ubatuba $\left(23^{\circ} 30^{\prime} 24^{\prime \prime}\right.$ to $23^{\circ} 35^{\prime} 18^{\prime \prime} \mathrm{S}$ and $44^{\circ} 59^{\prime} 00^{\prime \prime}$ to $\left.45^{\circ} 03^{\prime} 58^{\prime \prime} \mathrm{W}\right)$, on the northern coast of São Paulo. Skates were sampled monthly from January-December 2000, along four transects parallel to the coastline, at depths of 25, 30, 35, and $40 \mathrm{~m}$. Sampling was done from a shrimp boat equipped with a double-rig otter-trawl bottom net. Each sampling locality was approximately $2 \mathrm{~km}$ long, and was delimited by GPS (Global Positioning System) in order to determine the exact location of the transect. Each trawl was towed at 
two knots speed for about $30 \mathrm{~min}$, thus covering an area of $18000 \mathrm{~m}^{2}$.

Water samples were collected from the bottom using a Nansen bottle, which allowed us to record water temperature and salinity simultaneously. Temperature (accurate to $0.5^{\circ} \mathrm{C}$ ) was measured with a mercury thermometer, and salinity (psu) using an Atago S/1000 ${ }^{\circledR}$ optical refractometer.

The skates were recorded by transect as they were caught. They were then placed on ice and transported in insulated boxes to the Marine Biology laboratory of the University of Taubaté (UNITAU), where they were identified to species according to Figueiredo (1977) and Carvalho \& Figueiredo (1994). Each individual was labelled as to sex, sampling date, and transect depth. The total length (TL; nearest $0.1 \mathrm{~mm}$ ) and weight (biomass; nearest $0.01 \mathrm{~g})$ were measured.

In males, the clasper length (CL) was measured from the point of insertion at the cloaca to the tips of the claspers. The allometric increase in clasper length in relation to total length was estimated separately for immature and mature males, using the allometric equation $\mathrm{Y}=\mathrm{aX}^{\mathrm{b}}$ (Huxley, 1950; Gould, 1966). The slope derived for each regression was tested against the isometric slope standard of 1 with Student's $t$-test, to determine the type of allometric growth. The same procedure was carried out to describe the length-weight relationship for males and females. In this case, the slopes were tested for difference from the theoretical value of 3 (one measure is a volume), also with a $t$-test. The significance level was set at $5 \%$.

For each female the presence of egg cases in the oviduct, the oocyte diameter in the ovary (minimum and maximum), and the length and width of the egg capsule were measured. All measurements were taken with a digital caliper, to the nearest $0.1 \mathrm{~mm}$.

The stages of sexual maturity were identified in accordance with the following criteria, adapted from Walmsley-Hart et al. (1999):

Males. Stage I-Immature: claspers unstructured, shorter than pelvic fin tips, skeleton uncalcified. Sperm ducts appear as a thin white line along the dorsal surface of the abdominal cavity. Testes small, composed of undifferentiated tissue. Stage II-Maturing (sub adult): clasper skeleton partially calcified, but still soft and flexible. Claspers extending to near or beyond pelvic fin tips. Alar thorns developing. Sperm ducts beginning to thicken and coil. Testes becoming lobular. Stage III-Mature (adult): clasper skeleton wholly calcified and hard. Claspers extended much beyond pelvic fin tips. Field of alar thorns fully developed. Sperm ducts fully developed and coiled. Testes greatly enlarged.

Females: Stage I-Immature: ovaries consist of white (or transparent) undifferentiated tissue. No oocytes differentiated, or oocytes uniformly small. Oviducts appear as a thin line on the dorsal surface of the abdominal cavity. Nidimental gland undeveloped and little visible. Stage II-Maturing: ovaries carrying oocytes becoming differentiated into various small sizes. Oviducts begin to broaden. Nidimental gland visible and small but little developed. Stage III-Mature: ovaries full of oocytes, some of them very large. Oviducts totally developed, either containing egg cases or spent (uteri empty but still widened). Nidimental gland enlarged and fully developed,

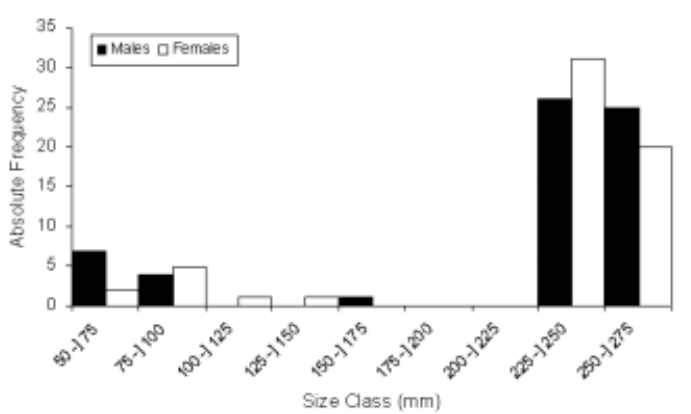

Figure 1. Distribution of males and females of Psammobatis extenta by size-classes, in the Ubatuba region, São Paulo, Brazil, from January to December 2000.

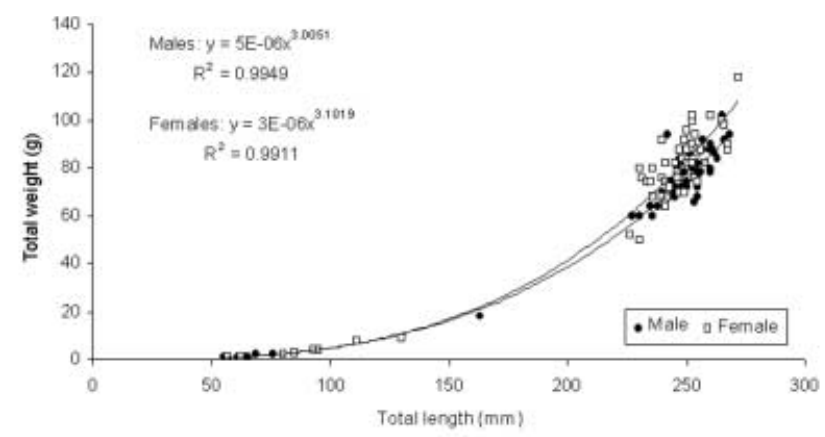

Figure 2. Relationship between total length $(\mathrm{mm})$ and total weight (g) for males and females of Psammobatis extenta, collected in the Ubatuba region, São Paulo, Brazil, from January to December 2000.

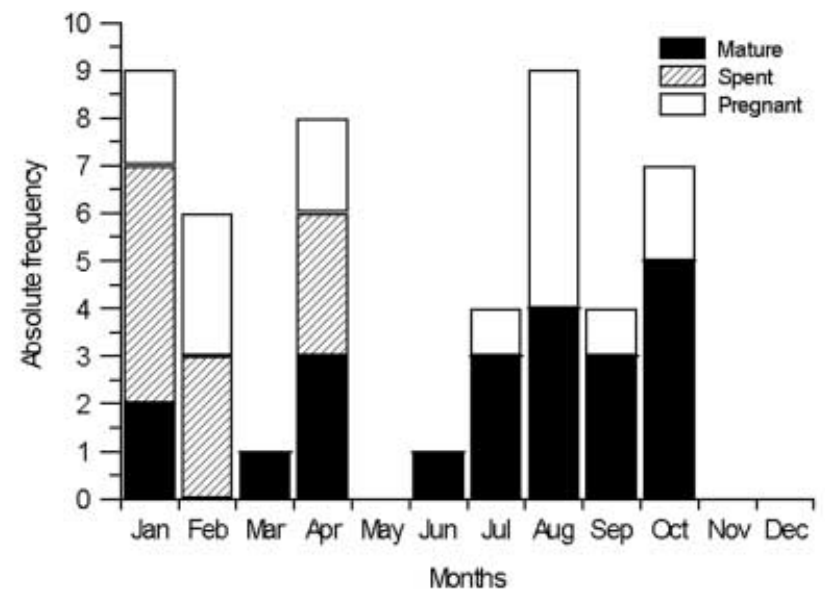

Figure 3. Occurrence of mature, post-partum (spent), and pregnant females of Psammobatis extenta by month in the Ubatuba region, São Paulo, Brazil, from January to December 2000 .

no egg capsule yet visible in gland, or egg capsule beginning to form.

The length at sexual maturity was obtained from the proportion of mature individuals (Stages II + III) in relation to immatures, in 10-mm size-classes. The size at 50\% $\left(\mathrm{TL}_{50}\right)$ maturity was determined by fitting a logistical regression to a plot of the per cent maturity versus total length. 


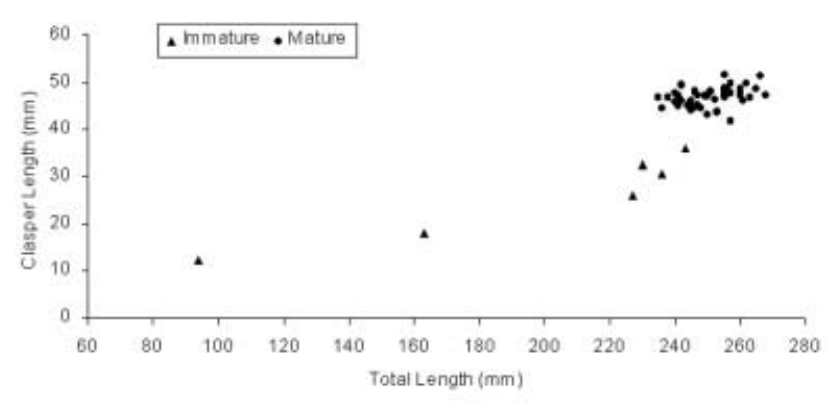

Figure 4. Relationship between clasper length and total length in males of Psammobatis extenta from the Ubatuba region, São Paulo, Brazil, from January to December 2000.

\section{RESULTS}

A total of 123 individuals of Psammobatis extenta were caught during the study period: $60(48.8 \%)$ females and $63(51.2 \%)$ males, of which 11 were immature females and 16 immature males. Of the immature individuals, 19 (9 females and 10 males) were neonates. The overall sex ratio did not differ significantly from $1: 1\left(\chi^{2}=0.057, \mathrm{df}=1\right.$, $P>0.05$.

Females had a mean TL of $224.6 \pm 58.7 \mathrm{~mm}$ (range 57$272 \mathrm{~mm}$ ). The TL of males was $217 \pm 69.9 \mathrm{~mm}$ (range 55$268 \mathrm{~mm})$.

To characterize the population structure, individuals were allocated to nine 25-mm length-classes. Most of the males and females fell in the largest size-classes (Figure 1), represented by adult specimens and constituting $83 \%$ of all the animals collected. The total biomass sampled was $8204 \mathrm{~g}$. Females had the highest mean biomass $(70.8 \pm 30.7 \mathrm{~g})$ ranging from 1.0 to $118 \mathrm{~g}$, while males ranged from 1.0 to $102 \mathrm{~g}$ with a mean weight of $62.8 \pm 30.5 \mathrm{~g}$. Females were generally larger and weighed more than males.

Allometric analyses of weight-length relationship were done for both males and females, to determine the growth type (Figure 2). The slopes of the allometric regressions were tested against the isometric slope standard of 3, with Student's $t$-test. Females showed positive allometric growth ( $t$-test, $t=2.68 ; P<0.05)$; for males the growth type was isometric $(t=0.18, P<0.05)$.

The largest immature female collected was $\mathrm{TL}=230 \mathrm{~mm}$, as was the smallest mature female (which had spent uteri). The smallest female with eggs in the uteri had $\mathrm{TL}=236 \mathrm{~mm}$. The proportion of mature females which had egg cases in the uteri was $32.6 \%$ of the total of adult (mature) females; females with egg cases were caught in seven of the 12 months of the study (Figure 3). A total of 11 females with spent uteri (i.e. postpartum) were collected in January, February, and April (Figure 3). These data suggest that in the Ubatuba region, $P$. extenta may reproduce continuously during the year.

We observed that in $P$. extenta, both ovaries are functional and uterine parity occurs, with an egg case lodged in each uterus. Females with ovaries containing oocytes of size and development stages varying from 3.12 to $13.9 \mathrm{~mm}$ and a mean size of $8.28 \pm 2.56 \mathrm{~mm}$ were caught throughout the year. The number of oocytes per ovary varied from 3 to 10 . The sizes of oocytes with large yellow yolks varied from 7.3 to $13.9 \mathrm{~mm}$. The mean length of the egg capsule (without horns) was $26.6 \pm 1.5 \mathrm{~mm}(24.34-29.23 \mathrm{~mm} ; \mathrm{N}=24)$, and the mean width was $18.6 \pm 0.77 \mathrm{~mm}(17.3-20.1 \mathrm{~mm}$; $\mathrm{N}=24$ ).

Males of $P$. extenta had the clasper skeleton wholly calcified and the testes developed beginning at $236 \mathrm{~mm}$ TL. The largest immature male had $235 \mathrm{~mm}$ TL.

An allometric analysis was carried out to determine the kind of growth of claspers in relation to body size. Two regression lines were fitted: one for individuals with clasper length up to $35.9 \mathrm{~mm}(\mathrm{~N}=6)$, with skeleton uncalcified (indicating immature and maturing males), and another for clasper lengths above 43.1 (with skeleton fully calcified, indicating sexual maturity, $\mathrm{N}=47$ ). In immature

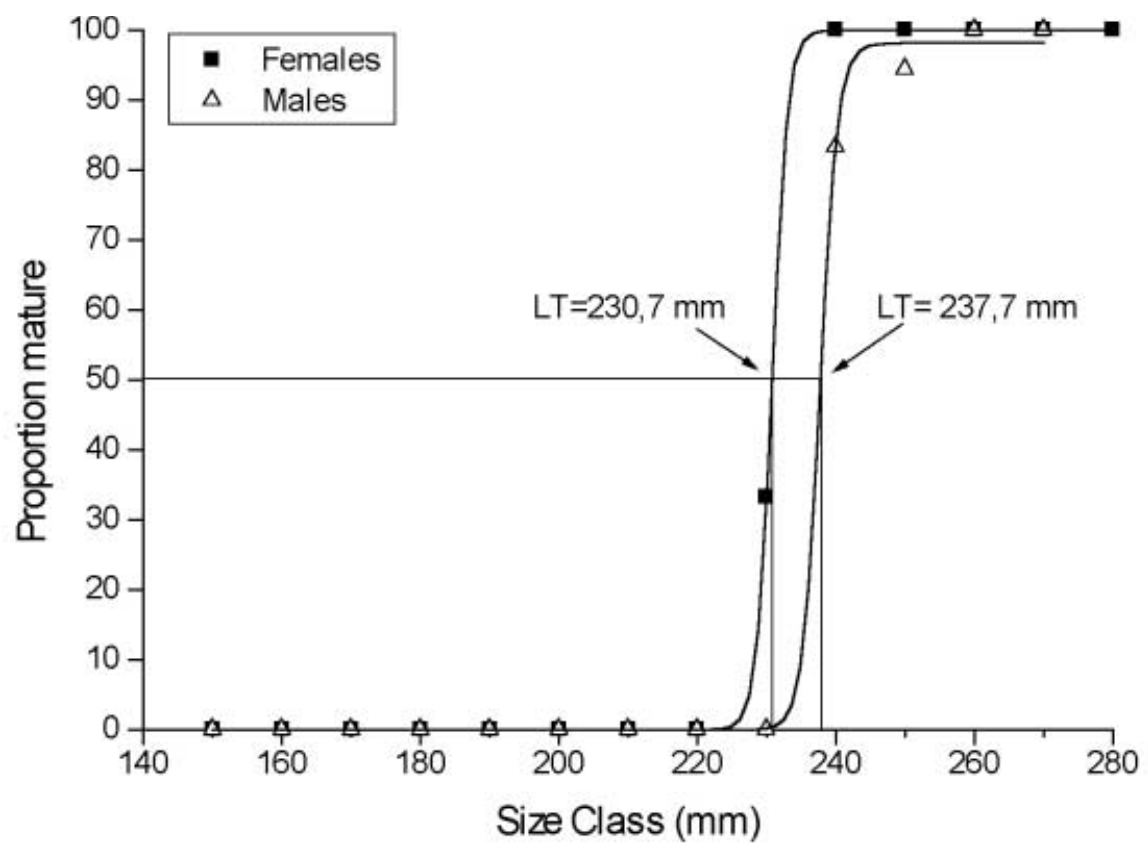

Figure 5. Proportion of mature individuals by size-classes. The arrows indicate the size at maturity, when $50 \%$ of individuals of Psammobatis extenta are considered mature. 


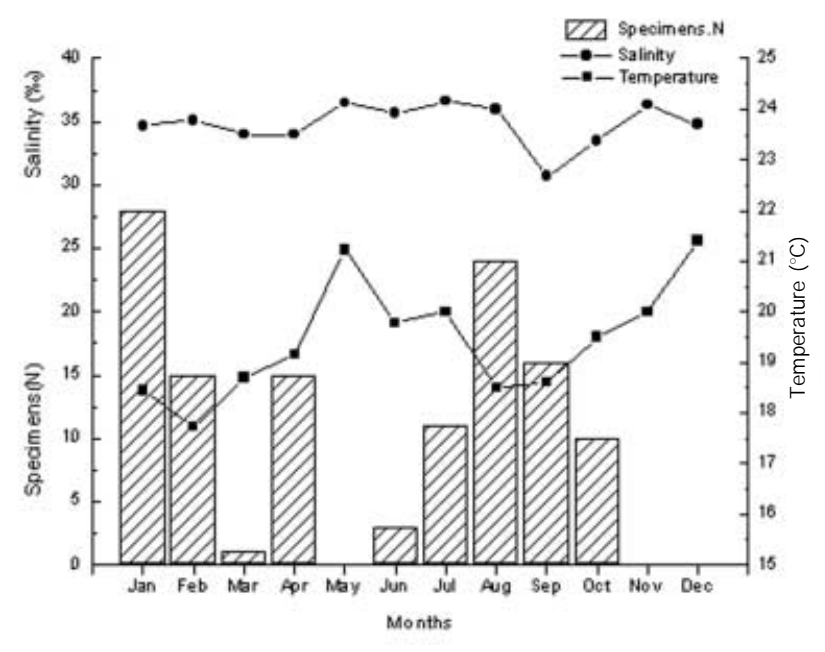

Figure 6. Numbers of individuals of Psammobatis extenta captured, mean salinity (psu), and mean temperatures of the bottom water $\left({ }^{\circ} \mathrm{C}\right)$, recorded monthly in the Ubatuba region, São Paulo, Brazil, from January to December 2000.

and adolescent males, the claspers showed isometric growth (equation for CL vs TL for immatures: $\mathrm{CL}=$ $\left.0.089 \mathrm{TL}^{1.068}\right)$. Mature males showed negative allometry $\left(\mathrm{CL}=3.137 \mathrm{TL}^{0.483}\right)$, indicating that the claspers grow more slowly after the males reach their adult size (Figure 4).

The size at onset of sexual maturity was determined by fitting a sigmoid logistical curve for both males and females, considering the proportion of mature individuals in each $10-\mathrm{mm}$ size-class. The size at sexual maturity estimated for females $\left(\mathrm{TL}_{50}=230.7 \mathrm{~mm}\right.$ ) was smaller than the estimated size for males $\left(\mathrm{TL}_{50}=237.7 \mathrm{~mm}\right.$ ), assuming the size of maturity at $50 \%$ (Figure 5 ).

The skates occurred in mainly two distinct periods: from January through April and from June through October (Figure 6). Immature individuals were collected in January, February, August, and September, constituting $25.3 \%$ of the total individuals collected in these months. Mature skates were collected in nine of the 12 months.

The highest number of individuals was collected along the $40-\mathrm{m}$ isobath $(\mathrm{N}=113,91.8 \%)$; only $8 \%$ of the total number was collected along the $30-$ and $35-\mathrm{m}$ isobaths. None was collected along the $25-\mathrm{m}$ isobath.

Temperature and salinity did not vary remarkably among the months and sub-areas sampled. The water temperature near the bottom remained stable, with a mean of $19.3 \pm 1.3^{\circ} \mathrm{C}$. The highest temperatures occurred in May and December $\left(21.2\right.$ and $21.4^{\circ} \mathrm{C}$ ), when no individual of $P$. extenta was caught. For the months in which the most occurrences were recorded, the mean water temperature was $18.4^{\circ} \mathrm{C}$ (Figure 6). However, there was no correlation between the temperature of the bottom water and the number of individuals caught in each month (Spearman correlation, $P>0.05$ ).

\section{DISCUSSION}

In this study, the maximum size of the individuals ( $272 \mathrm{~mm} \mathrm{TL})$ is similar to maxima reported by other researchers working off the coast of São Paulo State (Soares et al., 1992; Muto et al., 2001). Braccini \& Chiaramonte (2002) reported a larger maximum size
(313 mm TL) in their study, done at depths of 35-56 m at latitude $38^{\circ} 37^{\prime} \mathrm{S}$ off the coast of Argentina. These differences in size may result from different oceanographic conditions at these different latitudes.

Our data showed that in the Ubatuba region, the females attain larger sizes and heavier body weights than males. Among rajids it is common for females to grow larger than males. This is a consequence of their reproductive strategies, since females grow larger to hold the egg case within the body cavity, while males allocate energy to growth and reach sexual maturity at smaller sizes (Walmsley-Hart et al., 1999). Our results demonstrating that females mature at smaller sizes than males are similar to the results obtained by Branccini \& Chiaramonte (2002). These same authors suggested that Psammobatis extenta has a reproductive strategy different from other elasmobranchs; however they did not elaborate on this assumption.

Knowledge of chondrichthyan reproductive strategies is of fundamental importance, because, starting from observed patterns, population characteristics can be detected and understood (Wourms \& Demski, 1993).

The reproductive strategy of $P$. extenta involves the production of few and small embryos, and continuous reproduction during the year. These features do not explain why females reach maturity at smaller sizes than do males. However, the occurrence of reproductive events (such as reproduction and hatching/capsule deposition) in shallow waters (about $50 \mathrm{~m}$ deep) may expose the skates to greater risks associated with mortality from fishery activity. Off the northern coast of São Paulo, there is an intense commercial penaeid shrimp fishery at these depths, and several skate species including $P$. extenta are often taken as by-catch. Because of the small size and lack of commercial value of $P$. extenta, these skates are always discarded. Evolutionary pressure toward early maturation can be generated by intense fishery activity (Stevens et al., 2000). According to Frisk et al. (2001), rajid species may be more susceptible to decline due to high fishery exploitation, which would contribute to evolution toward smaller body size and early maturation. However, other factors such as the relatively warm waters of São Paulo State may also explain the differences in body size and maturity size between this population and that studied by Braccini \& Chiaramonte (2002) off Argentina.

In the Chondrichthyes, oviparity is a specialized strategy since the production of a small number of large eggs has been selected for (Wourms, 1977). The reproductive success and diversity of skate species attest to the advantages of this strategy. Oviparity is characteristic of the family Rajidae, and about $43 \%$ of the species of Recent Chondrichthyes are oviparous (Compagno, 1977). In addition to rajids, some sharks (Heterodontiformes and Orecolobiformes + most Scyliorhinidae) and chimaeras (Holocephalii) (Compagno, 1990) are also oviparous.

We observed that $P$. extenta shows functional parity of the ovaries and uterus. Each ovary contained 3-10 oocytes in different stages of development. Pregnant females showed simple oviparity, with only one egg capsule present in each uterus. This is a common feature among oviparous rajid species (Templeman, 1982); however, exceptions occur, e.g. Raja binoculata Girard, 1855, which has 2-7 embryos in each egg capsule (Hitz, 1964). 
According to Wourms (1977), chondrichthyans may have one of three basic types of reproductive cycles: (1) reproduction throughout the year or in most months; (2) a poorly defined annual cycle with one or two peaks; or (3) a well-defined annual or biennial cycle. Our results indicated that $P$. extenta has continuous reproductive activity, with no defined peaks. This assumption is based on the records of males with developed testes and calcified clasper skeletons throughout the year, as well as of females with vitellogenic oocytes (recorded in nine months of the study), or an egg case within the uterus (recorded in seven months).

Fast growth of claspers and subsequent calcification occurred in males larger than $236 \mathrm{~mm}$ TL. For the Argentina population of $P$. extenta (Braccini \& Chiaramonte, 2002), clasper growth occurred in males larger than $240 \mathrm{~mm}$ TL. This rapid increase in clasper size is related to the maturation process, which occurs in animals over a wide size range.

Collection of both adult and neonate elasmobranchs in a certain area might indicate that this area is a breeding ground. Indeed, we recorded both male and female adults (in 1:1 proportion) and also hatched neonates in the area sampled (at around $40 \mathrm{~m}$ depth). Braccini \& Chiaramonte (2002) suggested that the low number of young (in maturing stages) collected during the course of their study might be associated with differential occupation of the area between adults and young. The absence of individuals in intermediate size-classes (125 to $225 \mathrm{~mm}$ ) in our study reinforces the assumption that different growth stages of $P$. extenta occupy different areas, and that they use shallow areas as breeding grounds.

Analyses of certain aspects of populations, such as the stages of sexual maturity of the specimens caught, the presence of females and males (young and adult), reproductive cycles, and feeding can allow us to characterize the use of space by the population or group of species studied. According to Talent (1985), the quantity of food resources, competition, and reproductive processes can influence the pattern of seasonal distribution of many elasmobranchs. Muto et al. (2001), mentioned that the concentration of $P$. extenta around the $50-\mathrm{m}$ isobath was associated with the availability of the preferred prey, brachyuran and portunid crabs.

According to Rossi-Wongtschowski \& Paes (1993), the continental shelf off the northern coast of São Paulo, can be divided into two domains, an inner ( $0-50 \mathrm{~m} \mathrm{depth})$ and an outer (over $50 \mathrm{~m}$ ). Our study was conducted on the inner shelf. The movement of the ocean currents along the coast influences the oceanographic structure as much as the seasonal distribution of the organisms, and also the dynamics of the ecosystems of the region (Pires, 1992). During summer, the South Atlantic Central Water (SACW) penetrates to the inner shelf, causing stratification of the water column with the development of a thermocline. At this season, the upper layer (less than $20 \mathrm{~m}$ deep) is basically occupied by the CW (CoastalWater), which mixes with Tropical Water (TW) offshore; while the SACW predominates near the bottom. In the winter, the SACW retreats to the outer, deeper areas of the shelf and the thermocline disappears (Matsuura, 1986). The current patterns in this region are responsible for many of the observed seasonal patterns of occurrence of the various species.
Fagundes Netto \& Gaelzer (1991) recorded a displacement of the ichthyofauna from deeper (around $60 \mathrm{~m}$ ) to shallower areas (up to $30 \mathrm{~m}$ ) during spring and summer at Cabo Frio (Rio de Janeiro). This area is strongly influenced by maritime currents, and according to Fagundes Netto \& Gaelzer (1991), seasonal changes in the currents cause variations in the composition and abundance of the ichthyofauna.

The species $P$. extenta usually inhabits waters deeper than $50 \mathrm{~m}$ (Figueiredo, 1981; Rossi-Wongtschowski \& Paes, 1993). However, we recorded it in shallower waters, and in the Ubatuba region the upper limit is around 30 metres.

Several studies from south-west Atlantic have noted that rajid species occur in a seasonal rhythm. Fagundes Netto \& Gaelzer (1991) reported that Psammobatis bergi occurred in the spring and summer at Cabo Frio (Rio de Janeiro). Rossi-Wongtschowski \& Paes (1993) reported that Psammobatis glansdissimilis $(=P$. extenta) invaded the inner parts of the continental shelf during the summer. Their report is in disagreement with our finding of $P$. extenta in shallower waters for an extended period of the year, not only in the summer. According to Rossi-Wongtschowski \& Paes (1993), P. extenta is more related to the group of seasonal fish species, associated with the inflow and outflow of SACW in and from the region, and occurring in waters with low temperatures between 14 and $20^{\circ} \mathrm{C}$. On this point, we are in agreement with these authors, since the highest numbers of individuals were sampled when the bottom-water temperatures were below $20^{\circ} \mathrm{C}$.

We are grateful to the NEBECG group, especially Dr Adilson Fransozo (UNESP), for their great help and logistical support in the realization of this study. We also thank Dr Valter José Cobo (UNITAU), Dr Rogério Caetano da Costa (UFPR), and Dr Giovana Bertini, for their valuable help in fieldwork, and the students of the Laboratory of Zoology, UNITAU for their assistance in collecting samples. We also thank the Pró-reitoria de Pesquisa e Pós Graduação (PRPPG) for logistical and financial support.

\section{REFERENCES}

Braccini, J.M. \& Chiaramonte, G.E., 2002. Reproductive biology of Psammobatis extenta. Fournal of Fish Biology, 61, 272-288.

Carvalho, M.R. \& Figueiredo, J.L., 1994. Psammobatis extenta (Garman, 1913): a senior synonym of Psammobatis glansdissimilis McEachran, 1983 (Chondrichthyes, Rajidae). Copeia, 4, 10291033.

Compagno, L.J.V., 1977. Phyletic relationships of living sharks and rays. American Zoologist, 17, 303-322.

Compagno, L.J.V., 1990. Alternative life-history style of cartilaginous fishes in time and space. Environmental Biology of Fishes, 28, 33-75.

Fagundes Netto, E.B. \& Gaelzer, L.R., 1991. Associações de peixes bentônicos e demersais na região de Cabo Frio, RJ, Brasil. Nerítica, 6, 139-156.

Figueiredo, J.L., 1977. Manual de peixes marinhos do sudeste do Brasil. I. Introdução. Cações, raias e quimeras. São Paulo: Museu de Zoologia da Universidade de São Paulo.

Figueiredo, J.L., 1981. Estudo das distribuições endêmicas de peixes da Provincia Zoogeográfica Marinha Argentina. $\mathrm{PhD}$ thesis, Universidade de São Paulo, Instituto de Biociências, São Paulo, Brazil. 
Frisk, M.G., Miller, T.J. \& Fogarty, M.J., 2001. Estimation and analysis of biological parameters in elasmobranch fishes: a comparative life history study. Canadian Journal of Fisheries and Aquatic Sciences, 58, 969-981.

Hitz, C.R., 1964. Observations on egg cases of the big skate Raja binoculata Girard, found in Oregon coastal waters. Fournal of the Fisheries Research Board of Canada, 21, 851-864.

Huxley, J.S., 1950. Relative growth and form transformation. Proceedings of the Royal Society of London, Biological Sciences, 137, 465-469.

Gadig, O.B.F., 1998. Peixes cartilaginosos da costa do Estado de São Paulo. Ceciliana, VIII, 41-51.

Gould, S.J., 1966. Allometry and size in ontogeny and phylogeny. Biological Reviewes, 41, 587-640.

Mahiques, M.M., 1995. Dinâmica sedimentar atual nas enseadas da região de Ubatuba, Estado de São Paulo. Boletim do Instituto Oceanográfico, São Paulo, 43, 111-122.

Matsuura, Y., 1986. Contribuição ao estudo da estrutura oceanográfica da região sudeste entre Cabo Frio (RJ) e Cabo Santa Marta Grande (SC). Ciência e Cultura, 38, 1439-1450.

Muto, E.Y., Soares, L.S.H. \& Goitein, R., 2001. Food resource utilization of the skates Rioraja agassizii (Müller \& Henle, 1841) and Psammobatis extenta (Garman, 1913) on the continental shelf off Ubatuba, south-eastern Brazil. Revista Brasileira de Biologia, 61, 217-238.

Norman, J.R., 1937. Coast fishes, Part II. The Patagonian Region. Discovery Reports 16. Cambridge: Cambridge University Press.

Pires, A.M.S., 1992. Structure and dynamics of benthic megafauna on the continental shelf offshore of Ubatuba, southeastern Brazil. Marine Ecology Progress Series, 86, 63-76.

Rossi-Wongtschowski, G.L.D.B. \& Paes, E.T., 1993. Padrões espaciais e temporais da comunidade de peixes demersais do litoral norte do Estado de São Paulo-Ubatuba, Brasil. Publicação Especial do Instituto Oceanográfico, São Paulo, 10, 169-188.
Soares, L.S.H., Rossi-Wongtschowski, C.L.D.B., Alvares, L.M.C., Muto, E.Y. \& Gasalla, M.A., 1992. Grupos tróficos de peixes demersais da plataforma continental interna de Ubatuba, Brasil. I. Chondrichthyes. Boletim do Instituto Oceanográfico, São Paulo, 40, 79-85.

Stevens, J.D., Bonfil, R., Dulvy, N.K. \& Walker, P.A., 2000. The effects of fishing on sharks, rays, and chimaeras (chondrichthyans), and the implications for marine ecosystems. Fournal of Marine Science, 57, 476-494.

Talent, L.G., 1985. The occurrence, seasonal distribution, and reproductive condition of elasmobranch fishes in Elkhorn Slough, California. California Fish and Game, 71, 210-219.

Templeman, W., 1982. Development, occurrence and characteristics of egg capsules of thorny skates, Raja radiata, in the Northwest Atlantic. Fournal of Northwest Atlantic Fishery Science, $3,47-56$.

Walmsley-Hart, S.A., Sauer, W.H.H. \& Buxton, C.D., 1999. The biology of the skates Raja wallacei and $R$. pullopunctata (Batoidea: Rajidae) on the Agulhas Bank, South Africa. South African Fournal of Marine Science, 21, 165-179.

Wourms, J.P., 1977. Reproduction and development in chondrichthyan fishes. American Zoologist, 17, 379-410.

Wourms, J.P. \& Demski, L.S., 1993. The reproduction and development of sharks, skates, rays and ratfishes: introduction, history, overview, and future prospects. Environmental Biology of Fishes, 38, 7-21. 